\title{
ANALISIS PERBEDAAN ABNORMAL RETURN DAN CUMULATIVE ABNORMAL RETURN EMITEN SEKTOR KEUANGAN SEKITAR PEMILU 17 APRIL 2019
}

\author{
Cahyono Jagad Raya \\ Universitas Negeri Surabaya \\ Cahyonojagadr123@gmail.com \\ R.A. Sista Paramita \\ Universitas Negeri Surabaya \\ sistaparamita@unesa.ac.id
}

\begin{abstract}
This research was prepared using the event study method to analyze the Indonesian capital market reaction to a political event that can be seen from differences in abnormal returns and cumulative abnormal returns of shares before and after the general election event on 17 April 2019. The observation period carried out for 11 days consisted of 5 days before the event date, one-day event date, and 5 days after the event date. The population of the data used are financial sector companies listed in the period January to April 2019 on the Indonesia Stock Exchange, then the sample was taken using a purposive sampling obtained as many as 73 of 91 companies. While the data amalgamation technique uses the Wilcoxon Signed Rank Test because the data used doesn't meet the assumption of normality. The results showed that there were no differences in abnormal returns and cumulative abnormal returns of financial sector issuers between before and after the general election 17 April 2019. Therefore, the general election 17 April 2019 didn't contain important information for market participants so the market didn't overreact.
\end{abstract}

Keywords: abnormal return; cumulative abnormal return; event study.

\section{PENDAHULUAN}

Pasar modal berperan penting dalam pergerakan perekonomian suatu negara yang diharapkan dapat meningkatkan minat dan partisipasi masyarakat dalam berinvestasi. Pasar modal adalah pasar untuk berbagai instrumen keuangan jangka panjang (efek) yang bisa diperjualbelikan (Sasongko, Widiyanti, \& Taufik, 2015). Menurut Undang-Undang Nomor 8 Tahun 1995 Tentang Pasar Modal Tentang Pasar Modal, efek meliputi surat pengakuan utang, surat berharga komersial, saham, obligasi, sekuritas kredit, tanda bukti utang, right, waran, opsi, dan derivatif. Dalam perdagangan efek pihak investor sebagai pemilik modal harus bisa menganalisis dan menentukan instrumen keuangan apa yang dipilih sebagai alat investasi untuk menunjang jangka panjang dalam memberikan tingkat return yang diharapkan.

Pergerakan harga saham perusahaan terbuka di Indonesia dapat diketahui dari IHSG yang mencerminkan perkembangan perekonomian Indonesia karena didalamnya terdapat emiten baik BUMN maupun swasta yang menjadi sentral pendapatan negara. Jika kinerja keuangan perusahaan tidak stabil maka IHSG juga akan berpotensi menurun dan sebaliknya apabila kinerja keuangan stabil maka IHSG dan tingkat perekonomian Indonesia berpotensi meningkat. Penyebab ketidakstabilan dapat dipengaruhi oleh peristiwa ekonomi antara lain inflasi perubahan nilai tukar mata uang, kebijakan fiskal dan moneter, tingkat suku bunga, kebijakan dividen, strategi perusahaan maupun keputusan Rapat Umum Pemegang Saham. Sedangkan peristiwa non ekonomi salah satunya adalah event politic yang sangat sensitif dengan kondisi pasar modal (Luhur, 2010).

Hal tersebut akan mengikuti kecenderungan pasar yang dapat dipengaruhi oleh suatu peristiwa, salah satu peristiwa yang diperkirakan adalah Pemilihan Umum 2019 yang menjadi satu-satunya peristiwa pemilu di sepanjang tahun 2019. Pemilu yang dimaksud adalah pemilihan presiden dan wakil presiden disertai pemilihan legislatif (DPR, DPRD, dan DPD) yang dilaksanakan dalam satu hari bersamaan di berbagai wilayah dalam rangka pergantian pejabat pemerintah dan kegiatan pemilihan diikuti oleh seluruh rakyat Indonesia baik berdomisili dalam negeri maupun di luar negeri. Pemilihan Umum 2019 
ini diselenggarakan oleh Lembaga Independen yaitu Komisi Pemilihan Umum (KPU) RI dengan beberapa tahap pelaksanaan sebagai berikut (KPU, 2019):

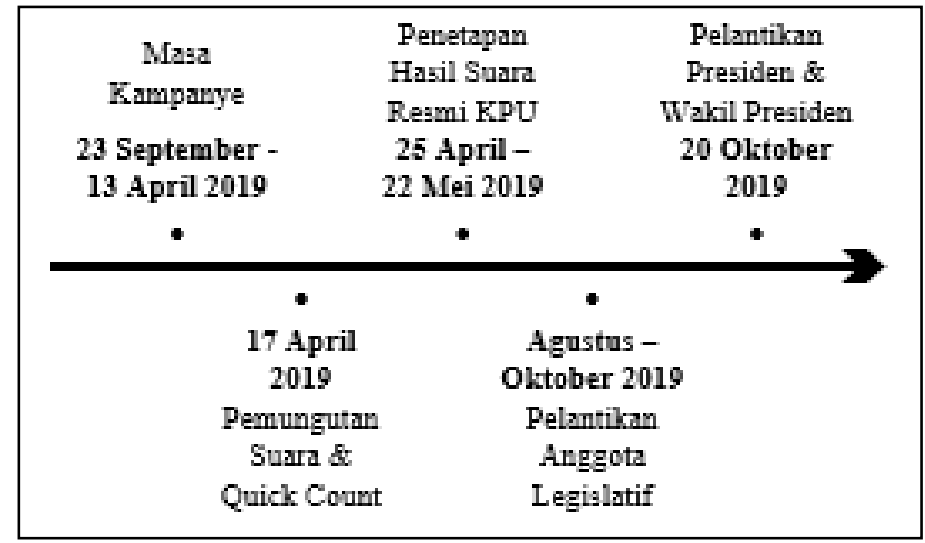

Sumber: Komisi Pemilihan Umum (2019)

\section{Gambar 1. TAHAP PELAKSANAAN PEMILU 2019}

Peristiwa yang menarik diuji kandungan informasinya dalam Pemilihan Umum 2019 yaitu sebelum dan sesudah pemungutan suara berlangsung, karena diperkirakan terdapat reaksi yang berdampak kuat terhadap pasar modal Indonesia seperti halnya pernyataan dari berita kompas bahwa IHSG menguat 51,2 poin ke posisi $6.532,7$ atau naik $0,79 \%$. Bahkan sehari sebelum pemilu (Selasa,16/04/2019) IHSG menguat 46,39 poin atau $0,72 \%$ ke posisi 6.481 dan dalam seminggu terakhir menguat $0,67 \%$. Selain itu pada pasca pemilu nilai rupiah pun menguat di level Rp. 14.000. Penguatan ini diyakini disebabkan adanya "Jokowi Effect" (Kompas.com, 2019). Berbeda dengan informasi dari berita liputan6 yang menyatakan bahwa yang menjadi factor "bukan Jokowi Effect, tetapi hanya jangka pendeknya". Berkaitan dengan peristiwa pemilu sektor keuangan menjadi pilihan investor karena indeks bobotnya dan kapitalisasi pasarnya lebih besar daripada sektor lainnya (Liputan6.com, 2019).

Pemilihan sektor keuangan juga didasarkan pada nilai kapitalisasi pasar dan bobot indeks aggregate lebih besar daripada sektor lainnya. Besar dari kapitalisasi pasar (market capital) perusahaan menjadi pengukuran dari keberhasilan atau kegagalan perusahaan, jika semakin besar tingkat market capital maka semakin mahal perusahaan dihargai oleh pasar begitu juga besarnya bobot indeks sektor jasa keuangan ikut mempengaruhi prospek pergerakan harga saham dari sektor lainnya maupun IHSG keseluruhan. Sama halnya ketika ekonomi Indonesia mengalami kemajuan pastinya sektor keuangan sangat diuntungkan karena lembaga jasa keuangan juga mengalami peningkatan seiring permintaan kredit untuk ekspansi usaha. Sejauh ini, hingga penutupan perdagangan Selasa (16/04/2019), sektor jasa keuangan berkontribusi 32,03 persen terhadap kapitalisasi pasar IHSG (Bareksa.com, 2019).

Berdasarkan peristiwa politik yang mempengaruhi reaksi bursa efek, maka peneliti tertarik melakukan penelitian event study untuk menguji kandungan informasi peristiwa Pemilihan Umum 17 April 2019. Menurut Hartono (2016: 643), pengujian kandungan informasi dimaksudkan untuk melihat reaksi dari suatu pengumuman. Jika pengumuman tersebut mengandung informasi, maka diharapkan pasar akan bereaksi pada saat pengumuman diterima. Reaksi pasar secara umum ditunjukan dengan adanya perubahan harga saham sekuritas terkait (Pratama, Sinarwati, \& Dharmawan, 2015). Reaksi pasar juga dapat dilihat dari ada tidaknya abnormal return setiap saham yang dimiliki investor. Abnormal return adalah selisih dari actual return dan expected return investor yang bisa terjadi sebelum dan sesudah informasi diterbitkan. Menurut Tandelilin (2017: 244) terkadang abnormal return harian tersebut digabungkan untuk menghitung return tak normal kumulatif selama periode tertentu dengan membandingkan cumulative abnormal return sebelum dan sesudah pengumuman diterbitkan.

Penelitian ini didukung oleh beberapa hasil penelitian terdahulu diantaranya oleh Diniar dan Kiryanto (2015); Achmadi dan Triani (2016); Katti (2018); Nazir, et al. (2014) dan Coulomb dan Sangnier (2014) yang membuktikan adanya perbedaan abnormal return sebelum dan sesudah peristiwa 
Pemilihan Umum. Berbeda dengan penelitian yang dibuktikan oleh Nabila dan Khairunnisa (2015); Pratama, Sinarwati, dan Dharmawan (2015); Melati, Saryadi, dan Widiartanto (2015); Luhur (2010); dan Suharyati dan Hermuningsih (2014) yang menghasilkan tidak adanya perbedaan abnormal return pada peristiwa Pemilihan Umum. Sedangkan beberapa hasil penelitian variabel cumulative abnormal return diantaranya oleh Niam, Achsani, dan Maulana (2018), Murekachiro (2014), yang membuktikan adanya perbedaan cumulative abnormal return pada peristiwa presidential election. Berbeda oleh Obradovic dan Tomic (2017), Kabiru, et al. (2015), dan Sudewa P. dan Sari (2015) yang membuktikan tidak adanya perbedaan abnormal return pada peristiwa presidential election. Penelitian ini bertujuan untuk mengetahui perbedaan abnormal return dan cumulative abnormal return emiten sektor keuangan antara sebelum dan sesudah peristiwa Pemilu 17 April 2019.

\section{KAJIAN PUSTAKA DAN PENGEMBANGAN HIPOTESIS}

\section{Teori Sinyal (Signaling Theory)}

Signalling theory merupakan suatu perilaku pihak manajemen perusahaan dalam memberikan pandangan pada investor terhadap prospek perusahaan di masa mendatang (Brigham \& Houston: 2014, 184). Selain itu teori ini juga menyatakan suatu peristiwa yang mengandung informasi akan memberikan sinyal kepada pasar modal termasuk pelaku pasarnya yaitu pengguna laporan keuangan yang mendapatkan informasi mengenai kegiatan yang telah dilakukan oleh pihak manajemen dan laporan tersebut memperlihatkan operasional berjalan dengan baik atau tidak (Rahmawati \& Achadiyah, 2015). Laporan keuangan (tahunan) akan memberikan informasi yang relevan dan dianggap penting untuk diketahui oleh pengguna laporan baik pihak internal maupun pihak eksternal. Terutama pihak eksternal (investor) yang membutuhkan informasi tersebut untuk menganalisis risiko setiap perusahaan sehingga dapat membentuk portofolio investasi dengan preferensi risiko yang diharapkan. Informasi yang diterima investor terlebih dahulu diterjemahkan sebagai sentimen baik maupun sentimen buruk. Teori ini digunakan dalam penelitian ini karena signaling theory menyatakan bahwa peristiwa politik akan memberikan sinyal kepada pasar karena partai pemenang pemilu memiliki kebijakan tersendiri mengenai pasar modal sehingga perhatian investor di pasar modal. Hal ini juga melihat banyak investor di BEI adalah investor asing (Diniar \& Kiryanto, 2015).

\section{Teori Asimetris Informasi}

Teori ini menyatakan adanya ketidakseimbangan informasi karena pihak yang berkaitan dengan perusahaan memiliki informasi yang berbeda mengenai prospek dan risiko perusahaan, hanya pihak tertentu yang memiliki informasi lebih baik dibandingkan pihak luar perusahaan (Hanafi: 2014, 217). Asimetris informasi terjadi karena pihak manajemen lebih superior menguasai informasi daripada pihak investor. Pencarian informasi tidak mudah karena pihak perusahaan tidak mau mengungkapkan semua informasi perusahaan kepada publik karena bersifat privasi. Berkaitan dengan menyikapi hal tersebut pihak investor harus cerdas dalam mencari informasi kemudian dilakukan analisis untuk memperoleh gambaran perusahaan baik atau buruknya. Informasi yang didapat akan berbeda antara pihak investor dan pihak internal perusahaan, hal inilah yang dikatakan sebuah informasi asimetris. Teori ini digunakan untuk menjelaskan perbedaan informasi yang diperoleh para pemegang saham sehingga abnormal return dan cumulative abnormal return yang diterimanya juga akan berbeda (Lisa, 2012).

\section{Event Study}

Menurut Hartono (2016: 643), studi peristiwa (event study) digunakan untuk mempelajari reaksi atas suatu event yang mempengaruhi pasar pada umumnya. Studi peristiwa digunakan menguji kandungan informasi dari suatu peristiwa untuk mengukur efisiensi pasar bentuk setengah kuat. Jika pasar bereaksi cepat atas informasi yang dipublikasi maka dapat dikatakan sebagai pasar efisien. Pada event study dikenal istilah jendela peristiwa (event windows) untuk menentukan periode pengamatan supaya tidak terganggu oleh event lain, tanggal peristiwa (event date) yaitu saat peristiwa itu terjadi, dan periode estimasi (estimation period).

Penelitian ini dilakukan untuk melihat reaksi yang terjadi adalah dengan menggunakan variabel abnormal return dan cumulative abnormal return untuk mengetahui ada tidaknya perbedaan kedua variabel sekitar peristiwa Pemilu 17 April 2019 pada emiten sektor keuangan. 


\section{Abnormal Return}

Return tak normal merupakan selisih antara actual return dan expected return pada setiap sekuritas (Hartono: 2016, 667). Formulasi perhitungan dapat dilihat rumus (1).

$A R_{i, t}=R_{i, t}-E\left[R_{i, t}\right]$

Keterangan:

$\mathrm{AR}_{\mathrm{i}, \mathrm{t}}$

$\mathrm{R}_{\mathrm{i}, \mathrm{t}}$

: Abnormal return sekuritas ke-i pada hari ke-t

$E\left[R_{i, t}\right]$

: Actual return sekuritas ke-i pada hari ke-t

: Expected return sekuritas ke-i pada hari ke-t

\section{Cumulative Abnormal Return}

Return tidak normal kumulatif merupakan jumlah abnormal return hari pertama sampai hari terakhir. (Hartono: 2016, 667). Formulasi rumus ditunjukan di rumus (2).

$\mathrm{CAR}_{\mathrm{i}, \mathrm{t}}=\sum_{\mathrm{a}=\mathrm{t} 5}^{\mathrm{t}} \mathrm{AR}$

Keterangan:

$\mathrm{CAR}_{\mathrm{i}, \mathrm{t}} \quad$ : Cumulative abnormal return sekuritas ke-i periode ke-t

$\mathrm{AR}$

: Abnormal return sekuritas ke-i hari ke-a (periode awal) sampai hari ke-t (akhir)

\section{Hipotesis}

H1: Terdapat perbedaan abnormal return saham pada emiten sektor keuangan sebelum dan sesudah peristiwa Pemilu 17 April 2019

H2: Terdapat perbedaan cumulative abnormal return pada emiten sektor keuangan sebelum dan sesudah peristiwa Pemilu 17 April 2019

\section{METODE PENELITIAN}

Jenis penelitian yang digunakan adalah penelitian komparatif atau perbedaan. Penelitian ini termasuk penelitian komparatif karena bertujuan untuk menganalisis perbedaan abnormal return dan cumulative abnormal return pada emiten sektor keuangan di sekitar peristiwa Pemilu 17 April 2019. Metode penelitian yang dilakukan adalah studi peristiwa (event study) untuk mengetahui reaksi pasar atas terjadinya peristiwa tertentu yang memiliki kandungan informasi atau tidak dan mengakibatkan pasar bereaksi, baik reaksi positif atau negatif (Hartono: 2016, 643).

Populasi penelitian ini adalah 91 emiten sektor keuangan dari 5 subsektor yang tercatat pada periode estimasi Januari-April 2019 di Bursa Efek Indonesia (BEI). Berdasarkan populasi tersebut dilakukan pengambilan sampel melalui teknik nonprobability sampling dengan metode purposive sampling dengan kriteria berikut ini: (1) Saham tercatat sebagai perusahaan sektor keuangan di BEI sekitar periode estimasi peristiwa. (2) Saham perusahaan yang aktif diperdagangkan sekitar periode peristiwa. (3) Perusahaan yang tidak melakukan corporate action di sekitar periode peristiwa dalam bentuk stock split, reverse stock split, buy back, delisting, merger, akuisisi, dan aktivitas penerbitan bukti right. Setelah melalui kriteria tersebut didapatkan sampel sebanyak 73 emiten pada sektor keuangan.

Teknik pengumpulan data penelitian ini menggunakan teknik dokumentasi yang dilakukan untuk mendapatkan data kuantitatif berupa angka dan bilangan seperti harga saham setiap sekuritas melalui halaman web Bursa Efek Indonesia (BEI) dan informasi pendukung atau referensi yang didapatkan melalui studi kepustakaan berbagai penelitian terdahulu yang relevan untuk melihat kaitan dengan penelitian ini. Teknik analisis data dilakukan melalui metode statistika dengan bantuan aplikasi $I B M$ SPSS 25 untuk memperoleh hasil yang bisa dinterpretasikan (Ghozali, 2018). Penelitian ini menggunakan teknik analisis uji beda t-test untuk menganalisis perbedaan abnormal return dan cumulative abnormal return antara sebelum dan sesudah Pemilu 17 April 2019 yang dilakukan sesuai beberapa tahap perhitungan maupun pengujian secara statistik. 
Cahyono Jagad Raya \& R.A. Sista Paramita. Analisis Perbedaan Abnormal Return dan Cumulative Abnormal Return Emiten Sektor Keuangan Sekitar Pemilu 17 April 2019

Pertama melakukan menentukan periode pengamatan atau jendela peristiwa (event windows) selama 11 hari bursa yang terdiri dari 5 hari sebelum event date, 1 hari event date, dan 5 hari sesudah event date. Kedua menghitung actual return untuk masing-masing sekuritas setiap hari selama event windows. Ketiga menghitung expected return yang menggunakan metode market adjusted model, karena metode tersebut banyak dipergunakan dalam penelitian terdahulu dan dianggap lebih mudah. Keempat menghitun abnormal return dan cumulative abnormal return setiap sekuritas yang diteliti. Kelima melakukan pengujian statistik deskriptif untuk mendeskripsikan data sehingga dapat diterjemahkan ke bahasa yang mudah dipahami seperti nilai minimal, maksimal dan rata-rata. Keenam menguji normalitas untuk melihat data variabel penelitian berdistribusi normal atau tidak.

Selanjutnya ketujuh melakukan pengujian hipotesis menggunakan uji beda $t$-test untuk membuktikan ada/tidak ada perbedaan abnormal return dan cumulative abnormal return sebelum dan sesudah peristiwa. Uji beda dilakukan dengan dua uji alternatif yaitu: Paired Sample T-Test adalah metode statistika parametrik yang dapat dilakukan jika datanya memenuhi asumsi normalitas dan Wilcoxon Signed Rank Test adalah metode statistik nonparametric yang dilakukan jika datanya tidak memenuhi asumsi normalitas. Kedua uji tersebut dapat dianalisis dengan taraf nyata sebesar 5\% $(0,05)$ sebagai berikut: Jika nilai signifikansi $<(0,05)$ maka hipotesis 1 dan 2 diterima, yang berarti terdapat perbedaan abnormal return dan cumulative abnormal return sebelum dan sesudah peristiwa. Tetapi jika nilai signifikansi $>(0,05)$ maka hipotesis 1 dan 2 ditolak, yang berarti tidak terdapat perbedaan abnormal return dan cumulative abnormal return sebelum dan sesudah peristiwa. Terakhir menganalisis hasil pengujian statistik dengan pembahasan yang jelas dan mudah dipahami.

\section{HASIL DAN PEMBAHASAN}

\section{Uji Statistik Deskriptif}

\section{Tabel 1. \\ HASIL UJI STATISTIK DESKRIPTIF ABNORMAL RETURN DAN CUMULATIVE ABNORMAL RETURN SEBELUM DAN SESUDAH PEMILU 17 APRIL 2019}

\begin{tabular}{cccr}
\hline Periode & Min & Max & \multicolumn{1}{l}{ Mean } \\
\hline AR t-5 & $-0,28099$ & 0,17660 & $-0,0026212$ \\
AR t-4 & $-0,14781$ & 0,16608 & 0,0058677 \\
AR t-3 & $-0,05777$ & 0,18879 & $-0,0007877$ \\
AR t-2 & $-0,06779$ & 0,13336 & $-0,0040601$ \\
AR t-1 & $-0,09054$ & 0,10683 & 0,0013412 \\
AR t+1 & $-0,04717$ & 0,16339 & 0,0026145 \\
AR t+2 & $-0,12159$ & 0,07095 & 0,0049159 \\
AR t+3 & $-0,15794$ & 0,13344 & $-0,0034311$ \\
AR t+4 & $-0,09525$ & 0,14316 & 0,0043327 \\
AR t+5 & $-0,11423$ & 0,04543 & 0,0019422 \\
Sebelum CAR & $-0,10256$ & 0,11398 & $-0,0002595$ \\
Sesudah CAR & $-0,12646$ & 0,12106 & 0,0103751 \\
\hline
\end{tabular}

Sumber: Data diolah.

Tabel 1 menunjukan hasil pengujian statistik deskriptif data 73 sekuritas perusahaan sektor keuangan selama 5 hari sebelum dan 5 hari sesudah Pemilu 17 April 2019. Pergerakan abnormal return mengalami peningkatan pada hari ke-1 sebelum peristiwa hingga hari ke-2 sesudah peristiwa dan baru mengalami kembali penurunan di hari ke-3 sesudah peristiwa. Sedangkan pergerakan cumulative abnormal return mengalami penurunan di periode sebelum peristiwa dan terjadi pergerakan peningkatan di sesudah peristiwa. Pergerakan kedua variabel juga dapat dilihat di gambar 2. 


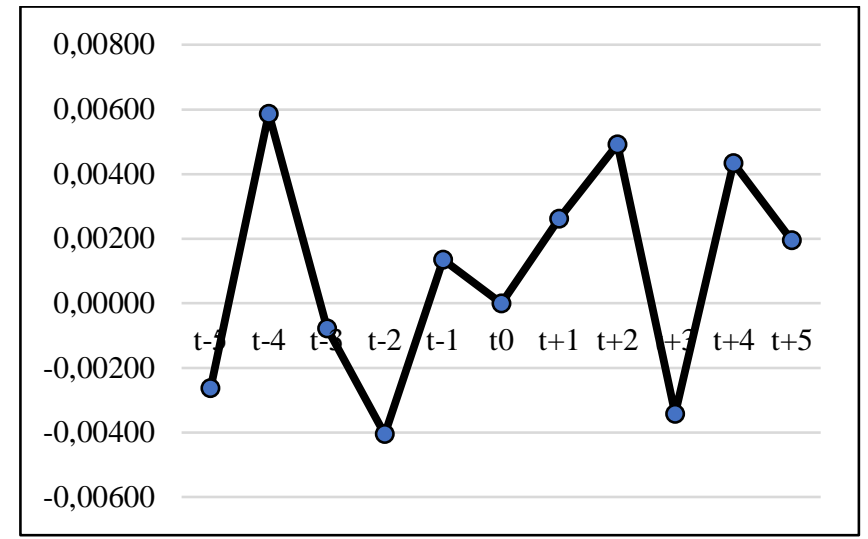

Sumber: Data diolah.

\section{Gambar 2. PERGERAKAN ABNORMAL RETURN}

Tampilan pada gambar $2 \mathrm{di}$ atas menunjukan bahwa pergerakan dimulai dengan menurunnya nilai abnormal return pada $\mathrm{t}-5$ sebesar $(-0,0026212)$ dan mengalami pergerakan peningkatan hingga $\mathrm{t}-4$ $(0,0058677)$. Hal tersebut disebabkan karena investor melakukan pemantauan dalam proses kampanye yang dilakukan kedua belah pihak tetapi dalam proses kampanye pihak Prabowo Subianto - Sandiaga Uno belum menunjukan keyakinan penuh kepada masyarakat untuk beralih pilihan dari pihak petahana, sehingga investor yakin bahwa Pemilu Presiden 2019 akan sama dengan hasil Pemilu Presiden di periode lalu. Jika hal ini terjadi, maka event politic akan memberikan sinyal baik bagi dunia usaha dengan tingkat kepastian yang jelas sehingga meningkatkan kepercayaan investor untuk berinvestasi pada saham-saham sektor keuangan yang semakin baik, sehingga harga saham mengalami bullish yang disebabkan permintaan saham melebihi tingkat penawaran. Namun pada t-3 abnormal return kembali turun sebesar $(-0,0007877)$ hingga $\mathrm{t}-2$ sebesar $(-0,0040601)$, kemudian nilai abnormal return kembali menguat pada t-1 yaitu sebesar $(0,0013412)$. Penurunan yang terjadi karena pelaku pasar melepas saham-saham yang telah memberikan capital gain dan terjadi penyesuaian setelah dua hari sebelumnya mendapatkan return dari peningkatan harga saham,

Pada periode peristiwa $\mathrm{t}+1$ yaitu sehari setelah tanggal 17 April 2019, abnormal return mengalami reaksi positif sebesar $(0,0026145)$ dan pergerakan abnormal return cenderung mengalami peningkatan hingga $t+2$ yaitu sebesar $(0,0049159)$. Reaksi positif ini disebabkan oleh adanya informasi yang diberikan Lembaga Quick Count yang terverifikasi KPU memenangkan pihak petahana pasangan Joko Widodo - Ma'ruf Amin sebesar 55,41\% (Cnnindonesia, 2019). Hal ini menimbulkan kepastian investasi yang disambut baik oleh investor dengan lebih cenderung melakukan pembelian saham sehingga terjadi peningkatan indeks harga saham pada emiten sektor keuangan. Namun kembali menurun secara signifikan pada $t+3$ atau tanggal 23 Apri019 yaitu sebesar (-0,0034311). Hal ini berkaitan dengan Real Count KPU yang lagi-lagi mengumumkan keunggulan sementara pihak petahana Joko Widodo - Ma'ruf Amin, tetapi kali ini menunjukan sentimen yang berbeda dikarenakan adanya berita hoaks yang mengklaim bahwa pihak Prabowo Subianto - Sandiaga Uno unggul sementara dibandingkan kandidat petahana (Kominfo, 2019). Hal ini akan berpotensi menyebabkan sentimen pasar mengalami penurunan karena investor merasa khawatir jika berbalik kondisi yang telah diprediksi sebelumnya. Sedangkan pada periode $t+4$ mengalami peningkatan sebesar $(0,00443327)$ dan sedikit menurun pada $\mathrm{t}+5$ sebesar $(0,0019422)$. Adanya penurunan abnormal return karena pelaku pasar cenderung untuk profit taking dengan melepas saham miliknya daripada melakukan pembelian saham.

Tampilan pada tabel 1 juga menunjukan variabel cumulative abnormal return (CAR) sekitar Pemilu 17 April 2019 yang mengalami kecenderungan penurunan pada sebelum event dan peningkatan pada sesudah event. Hal ini dibuktikan dengan nilai rata-rata CAR sebelum peristiwa sebesar $(-0,0002595)$, sedangkan sesudah Pemilu 17 April 2019 nilai rata-rata CAR menjadi sebesar $(0,0103751)$. Sentimen negatif pada periode sebelum peristiwa diakibatkan adanya kekhawatiran pasar, jika dari pihak yang kalah dalam hasil pemungutan suara akan melakukan kerusuhan politik hingga kerusuhan yang terjadi dijalanan yang mengganggu ketidakstabilan keamanan negara dan berdampak pada perekonomian. 
Namun faktanya hal tersebut tidak terjadi sehingga pasar modal ini hanya berlangsung sesaat ketika terjadi pelemahan yang dimanfaatkan untuk melakukan pembelian saham terutama pada sektor keuangan yang terkena sell action. Melainkan sentimen positif pada periode sesudah peristiwa disebabkan adanya kepastian investasi setelah mengetahui hasil pemungutan suara dari Lembaga Quick Count yang terverifikasi KPU mengumumkan keunggulan satu pasangan calon yang diharapkan investor serta didikung dengan hasil Real Count KPU yang mengumumkan sementara keunggulan Joko Widodo - Ma'ruf Amin yang kemudian menimbulkan kepercayaan investor untuk berinvestasi pada saham sektor keuangan yang merupakan sektor utama dalam mendukung pendanaan dari seluruh sektor, salah satunya yang paling terlihat publik dalam pembangunan Indonesia yaitu sektor Insfrastuktur.

\section{Uji Normalitas}

Pengujian normalitas dilakukan dengan metode pengujian statistik menggunakan Kolomogorov Smirnov Test dapat dikatakan berdistribusi normal jika variabel abnormal return dan cumulative abnormal return baik sebelum dan sesudah peristiwa memenuhi kriteria hipotesis berikut. Jika nilai Asymp, Sig. > $(0,05)$ maka H0 diterima atau data berdistribusi normal. Jika nilai Asymp, Sig. $<(0,05)$ maka $\mathrm{H} 0$ ditolak atau data tidak berdistribusi normal.

Tabel 2.

\section{HASIL UJI NORMALITAS}

\begin{tabular}{lcc}
\hline & Asymp, Sig. & Hasil \\
\hline T-5 Hari AR & 0,000 & Tidak Normal \\
T+5 Hari AR & 0,000 & Tidak Normal \\
T-5 Hari CAR & 0,001 & Tidak Normal \\
T+5 Hari CAR & $0, .070$ & Normal \\
\hline Sumber: Data diolah & &
\end{tabular}

Sumber: Data diolah.

Tabel 2 menunjukan hasil pengujian normalitas data abnormal return baik 5 hari sebelum dan 5 hari sesudah peristiwa tidak berdistribusi normal yang dibuktikan dengan nilai Asymp, Sig. $(0,0000)<$ $(0,05)$. Pada tabel 2 juga mengungkapkan bahwa data cumulative abnormal return 5 hari sebelum peristiwa memperoleh nilai Asymp, Sig. $(0,001)<(0,05)$ berarti data tidak berdistribusi normal, sedangkan 5 hari sesudah peristiwa memperoleh hasil $(0,070)>(0,05)$ maka data berdistribusi normal. Dengan demikian kesimpulannya data cumulative abnormal return tidak berdistribusi normal, karena terdapat satu periode yang tidak memenuhi asumsi normalitas.

\section{Uji Hipotesis}

Pengujian hipotesis penelitian ini bertujuan untuk mengetahui perbedaan abnormal return dan cumulative abnormal return emiten sektor keuangan sebelum dan sesudah Pemilu 17 April 2019 melalui uji nonparametric yaitu Wilcoxon Signed Rank Test karena data yang digunakan tidak berdistribusi secara normal. Berikut hasil pengujiannya:

Tabel 3.

HASIL UJI BEDA ABNORMAL RETURN DAN CUMULATIVE ABNORMAL RETURN SEBELUM DAN SESUDAH PEMILU 17 APRIL 2019

\begin{tabular}{ccc}
\hline Periode & Asymp, Sig. & Hasil \\
\hline AR $t+5 ; \mathrm{t}-5$ & 0,122 & \\
AR t $+4 ; \mathrm{t}-4$ & 0,223 & Tidak Signifikan \\
AR $\mathrm{t}+3 ; \mathrm{t}-3$ & 0,300 & \\
AR $\mathrm{t}+1 ; \mathrm{t}-1$ & 0,919 & \\
AR $\mathrm{t}+2 ; \mathrm{t}-2$ & 0,000 & Signifikan \\
Sebelum- Sesudah CAR & 0,055 & Tidak Signifikan \\
\hline
\end{tabular}

Sumber: Data diolah. 


\section{Perbedaan Abnormal Return Sebelum dan Sesudah Pemilu 17 April 2019}

Tampilan pada tabel 3 menunjukan hasil pengujian perbedaan abnormal return secara harian baik t5, $\mathrm{t} 4$, $\mathrm{t} 3$, dan $\mathrm{t} 4$ memperoleh hasil lebih besar dari tingkat probabilitas berarti secara statistik periode tersebut membuktikan tidak adanya perbedaan yang signifikan. Hal ini juga mengindikasikan dalam periode tersebut pasar tidak bereaksi terhadap peristiwa Pemilu 17 April 2019. Di samping itu pada periode $\mathrm{t} 2$ memperoleh hasil yang berbeda lebih kecil dari tingkat probabilitas berarti secara statistik periode tersebut terdapat perbedaan abnormal return. Hal ini membuktikan adanya reaksi yang disebabkan oleh perbedaan sentimen hari ke-2 sebelum peristiwa ( $\mathrm{t}-2)$ yang menunjukan penurunan dan hari ke-2 sesudah peristiwa $(\mathrm{t}+2)$ menunjukan adanya peningkatan sesuai hasil dari tabel 1 . Penurunan pada t-2 diakibatkan adanya penjualan saham yang dilakukan investor untuk mendapatkan return sehingga mengalami penyesuaian dari peningkatan di hari sebelumnya. Sedangkan peningkatan pada $\mathrm{t}+2$ disebabkan adanya sentimen baik dari hasil pemungutan suara yang mengumumkan keunggulan Joko Widodo - Ma'ruf Amin sementara versi Real Count KPU $(55,02 \%)$ suara (Cnbcindonesia, 2019).

Perbedaan abnormal return pada $\mathrm{t}+2$; $\mathrm{t}-2$ dan hanya memiliki reaksi pada pasar modal dikarenakan dalam periode tersebut menunjukan perbedaan sentimen dan nilai rata-ratanya sesuai pada tabel 1 , beda halnya dengan $\mathrm{t}+5 ; \mathrm{t}-5$ memang terlihat memiliki nilai rata-rata positif dan negatif tetapi menunjukan sentimen yang menurun. Bahkan perbandingan $\mathrm{t}+4 ; \mathrm{t}-4, \mathrm{t}+3 ; \mathrm{t}-3, \mathrm{t}+1 ; \mathrm{t}-1$ memiliki nilai rata-rata dan sentimen yang sama baik peningkatan maupun penurunan sehingga dalam periode tersebut tidak mengindikasikan adanya perbedaan. Berdasarkan hasil pengujian secara keseluruhan (mayoritas) maka hipotesis pertama ditolak yang berarti tidak terdapat perbedaan abnormal return emiten sektor keuangan antara sebelum dan seudah Pemilu 17 April 2019, meskipun terdapat satu periode yang menyatakan adanya perbedaan tetapi satu periode tidak bisa menggambarkan hasil perbedaan secara umum.

\section{Perbedaan Cumulative Abnormal Return Sebelum dan Sesudah Pemilu 17 April 2019}

Tampilan pada tabel 3 juga menunjukan hasil uji beda cumulative abnormal return dengan hasil lebih besar dari tingkat probabilitas maka hipotesis kedua juga ditolak atau hasil tersebut membuktikan tidak adanya perbedaan cumulative abnormal return emiten sektor keuangan antara sebelum dan sesudah Pemilu 17 April 2019. Selain itu jika dilihat dari nilai rata-rata cumulative abnormal return pada periode sebelum peristiwa lebih rendah dari nilai rata-rata sesudah peristiwa. Hal tersebut dapat diartikan adanya sentimen positif pada periode sesudah yang berdampak pada pergerakan peningkatan saham emiten sektor keuangan sesudah Pemilu 17 April 2019. Sentimen positif dapat disebabkan karena adanya investor yang cermat akan informasi sehingga sudah mengetahui siapa bakal kandidat terpilih kemudian memanfaatkan momen tersebut untuk mencari return di atas normal. Bahkan sentimen positif juga dapat disebabkan karena pada saat sesudah event kondisi pasar lebih tenang sehingga investor merasa aman untuk berinvestasi dibandingkan masa sebelum event investor merasa penuh ketidakpastian sehingga lebih cenderung pada sentimen negatif.

Signaling theory menyatakan bahwa peristiwa mengandung informasi yang memberikan sinyal terhadap pasar modal terutama kepada investor dalam menentukan keputusan investasi sehingga diharapkan pasar modal bereaksi atas peristiwa tersebut (Rahmawati \& Achadiyah, 2015). Hasil penelitian ini menunjukan tidak adanya perbedaan abnormal return dan cumulative abnormal return emiten sektor keuangan antara sebelum dan sesudah Pemilu 17 April 2019. Hasil tersebut membuktikan bahwa pasar tidak bereaksi, karena peristiwa Pemilu 17 April tidak memberikan sinyal kepada pasar sehingga signaling theory dalam penelitian ini tidak terdukung.

Hal ini juga berkaitan dengan teori asimetris informasi yang menyatakan adanya ketidakseimbangan informasi mengenai prospek dan risiko perusahaan yang diberikan pihak manajemen perusahaan kepada para pemegang saham sehingga terjadi perbedaan abnormal return dan cumulative abnormal return yang akan diterima investor (Hanafi: 2014, 217). Berdasarkan hasil yang tidak mendukung teori sebelumnya (signaling theory) karena terbukti tidak adanya reaksi sehingga tidak ada perbedaan abnormal return dan cumulative abnormal return yang diterima investor, maka teori asimetris informasi dalam penelitian ini tidak teruji keberlakuannya. 
Menurut Hartono (2016: 643) event study digunakan untuk menguji kandungan informasi dari suatu peristiwa dan mengukur efisiensi pasar bentuk setengah kuat. Jika pasar bereaksi cepat atas informasi yang dipublikasi maka dapat dikatakan sebagai pasar efisien bentuk setengah kuat. Pemilu 17 April 2019 merupakan peristiwa bagi seluruh rakyat Indonesia dan menjadi informasi yang disebarluaskan kepada publik sehingga diharapkan berpengaruh signifikan terhadap harga sekuritas di pasar modal. Namun informasi tersebut tidak cukup mempengaruhi keputusan investasi oleh investor di pasar modal. Hal ini dibuktikan dengan tidak adanya perbedaan abnormal return dan cumulative abnormal return sebelum dan sesudah Pemilu 17 April 2019. Maka kesimpulannya pasar efisiennya tidak jelas dan tidak terjawab karena pasar tidak bereaksi atas informasi yang dipublikasikan (Hartono (2016: 645).

Berdasarkan hasil pengujian statistik kedua hipotesis penelitian di atas memberikan implikasi bahwa hal tersebut disebabkan oleh beberapa faktor diantaranya: Pertama, berdasarkan beberapa tahap Pemilu 2019 yaitu selain tahap pelaksanaan pemungutan suara, sepertinya waktu yang dinantikan oleh investor karena menunggu kepastian kandidat terpilih yang memiliki kebijakan inovatif dan mampu membawa pemerintahan lebih baik kedepannya. Pada masa pemungutan suara, investor sepertinya masih merasa dilema untuk berinvestasi dalam jumlah tertentu karena penuh dengan ketidakpastian dan berisiko. Demikian hal ini yang menyebabkan sentimen investor cenderung stabil dan pasar tidak terlalu bereaksi.

Kedua, ketika ekonomi melaju kencang, sektor keuangan khususnya perbankan berpotensi memberikan keuntungan karena adanya prospek peningkatan kredit seiring dengan kemenangan Joko Widodo Ma'ruf Amin versi Lembaga Quick Count yang terverifikasi KPU. Di samping itu sektor keuangan juga memiliki tingkat market cap dan indeks bobot lebih tinggi yang mempengaruhi prospek pergerakan harga saham sektor lainnya (Bareksa, 2019). Namun kandidat petahana lebih dikenal publik dengan pembangunan infstruktur menyeluruh sehingga investor cenderung memutuskan investasi di saham sektor infrastruktur. Dengan demikian informasi yang diterbitkan telah pembicaraan umum bagi investor dan dapat diantisipasi sebelumnya.

Ketiga, kebijakan untuk membangun kualitas bangsa dan negara merupakan prioritas utama pemerintahan. Dalam mewujudkan hal tersebut tentunya pemerintahan memerlukan kerjasama dari berbagi pihak baik dalam negeri maupun pihak asing terutama dukungan dana yang didapatkan dari penawaran investasi di Indonesia kemudian dijadikan stimulus untuk melakukan pembangunan pada segala aspek. Dengan kebijakan itu menimbulkan adanya aliran dana asing yang masuk ke Indonesia itu menjadi pendorong stabilitas saham perusahaan di Indonesia.

\section{KESIMPULAN}

Berdasarkan hasil analisis dan pembahasan maka kesimpulan dari kedua hipotesis penelitian ini menunjukan bahwa tidak terdapat perbedaan abnormal return dan cumulative abnormal return pada emiten sektor keuangan sebelum dan sesudah Pemilu 17 April 2019. Hasil penelitian ini juga tidak mendukung signaling theory dan teori asimetris informasi karena dalam metode event study tidak menunjukan tidak adanya reaksi terhadap pasar modal terutama pada pelaku pasar (investor). Hal ini diperkirakan disebabkan beberapa factor, yaitu sentimen pelaku pasar yang cenderung stabil, peristiwa telah diketahui oleh masyarakat luas sehingga menjadi informasi umum yang dapat diantisipasi investor, serta adanya aliran dana asing yang masuk ke pasar modal Indonesia di tahun 2019 dan menjadi pendorong stabilitas indeks saham sektor keuangan sehingga pasar tidak terlalu bereaksi.

Bukti empiris penelitian ini menunjukan bahwa peristiwa memiliki muatan informasi, sehingga apabila investor lebih mencermati peristiwa tersebut mereka dapat lebih berhati-hati dalam memutuskan transaksi di pasar modal tanpa mengabaikan faktor lainnya. Penelitian selanjutnya dapat mempertimbangkan jenis informasi akan menghasilkan informasi yang relevan terhadap pasar modal. Penentuan event windows perlu dikaji apakah ada peristiwa lain yang menjadi confounding effect. Begitu juga dengan estimasi expected return, penelitian selanjutnya disarankan untuk membandingkan hasil perhitungan ketiga model yaitu mean adjusted model, market adjusted model, dan market model untuk mengetahui dampak terhadap hasil penelitian. 


\section{DAFTAR PUSTAKA}

Achmadi, H. R., \& Triani, N. N. A. (2016). Studi Perbandingan Kinerja Perusahaan Telekomunikasi Sebelum Dan Sesudah Pemilu Di BEI Tahun 2014. Jurnal Ilmu Manajemen (JIM), 4(2).

Bareksa.com. (2019). IHSG Selalu Naik Saat Tahun Pemilu, Sektor Mana Jadi Pilihan? Retrieved March 13, 2020, from https://www.bareksa.com/id/text/2019/02/25/ihsg-selalu-naik-saat-tahunpemilu-sektor-mana-jadi-pilihan/21697/news

Brigham, E. F., \& Houston, J. F. (2014). Dasar-Dasar Manajemen Keuangan Esential of Financial Management (11th ed.). Salemba Empat.

Cnbcindonesia.com. (2019). Real Count KPU 20.45 WIB: Jokowi 55,02\% \& Prabowo 44,98\%. Retrieved May 12, 2020, from https://www.cnbcindonesia.com/news/20190422210525-468135/real-count-kpu-2045-wib-jokowi-5502-prabowo-4498

Cnnindonesia.com. (2019). Hasil Quick Count Pilpres Tak Meleset dari Hitung Resmi KPU. Retrieved May 12, 2020, from https://www.cnnindonesia.com/nasional/20190521061318-32396711/hasil-quick-count-pilpres-tak-meleset-dari-hitung-resmi-kpu

Coulomb, R., \& Sangnier, M. (2014). The Impact of Political Majorities on Firm Value : Do Electoral Promises or Friendship Connections Matter? In Aix Marseille School of Economics Working Papers.

Diniar, A. H., \& Kiryanto. (2015). Analisis Dampak Pemilu Presiden Jokowi Terhadap Return Saham (Studi Kasus Saham LQ-45 di Bursa Efek Indonesia). Jurnal Akuntansi Indonesia, 4(2), 97-108. https://doi.org/10.30659/jai.4.2.97-108

Ghozali, I. (2018). Aplikasi Analisis Multivariate dengan Program IBM SPSS 25 (9th ed.). Semarang: Badan Penerbit Universitas Diponegoro.

Hanafi, M. M. (2014). Manajemen Keuangan (2nd ed.). Yogyakarta: BPFE.

Hartono, J. (2016). Teori Portofolio dan Analisis Investasi (Kesebelas). Yogyakarta: BPFE.

Kabiru, J. N., Ochieng, D. E., \& Kinyua, H. W. (2015). The Effect of General Elections on Stock Returns At the Nairobi Securities Exchange. European Scientific Journal, 11(28), 435-460.

Katti, S. W. B. (2018). Pengaruh Peristiwa Politik (Pemilu Presiden dan Pengumuman Susunan Kabinet) Terhadap Saham Sektor Industri Di Bursa Efek Indonesia. Capital Journal, 1(2), 125134.

Kominfo.co.id. (2019). Kementerian Komunikasi dan Informatika. Retrieved May 12, 2020, from https://www.kominfo.go.id/content/detail/18217/hoaks-23-april-2019-prabowo-sandi-unggul602/0/laporan_isu_hoaks

Kompas.com. (2019). “Jokowi Effect," Saham Sektor Infrastruktur dan Properti Bakal Melesat. Retrieved March 13, 2020, from https://money.kompas.com/read/2019/04/19/092905926/jokowi-effect-saham-sektorinfrastruktur-dan-properti-bakal-melesat

KPU.go.id. (2019). KPU - Portal Publikasi Pileg 2019. Retrieved June 15, 2020, from https://infopemilu.kpu.go.id/pileg2019

Liputan6.com. (2019). Meneropong IHSG dan Sektor Saham Pilihan Usai Pemilu 2019 - Bisnis 
Cahyono Jagad Raya \& R.A. Sista Paramita. Analisis Perbedaan Abnormal Return dan Cumulative Abnormal Return Emiten Sektor Keuangan Sekitar Pemilu 17 April 2019

Liputan6.com. $\quad$ Retrieved $\quad$ March 13, 2020, from https://www.liputan6.com/bisnis/read/3945130/meneropong-ihsg-dan-sektor-saham-pilihanusai-pemilu-2019

Lisa, O. (2012). Asimetri Informasi dan Manajemen Laba: Suatu Tinjauan dalam Hubungan Keagenan. Jurnal WIGA, 2(1), 42-49. Retrieved from https://media.neliti.com/media/publications/36615ID-asimetri-informasi-dan-manajemen-laba-suatu-tinjauan-dalam-hubungan-keagenan.pdf

Luhur, S. (2010). Reaksi Pasar Modal Indonesia Seputar Pemilihan Umum 8 Juli 2009 pada Saham LQ45. Jurnal Keuangan Dan Perbankan, 14(2), 249-262.

Melati, D. A., Saryadi, \& Widiartanto. (2015). Analisis Reaksi Pasar Modal atas Peristiwa Pemilihan Presiden 9 Juli 2014 (Event Study pada Indeks Saham LQ-45). Jurnal Ilmu Administrasi Bisnis, 4(2), 284-294.

Murekachiro, D. (2014). Opinion polls and the stock market: Evidence from the 2008 US presidential election. Journal of Financial, 2(4), 1-9.

Nabila, F., \& Khairunnisa. (2015). Analisis Perbedaan Abnormal Return Sebelum dan Sesudah Peristiwa Politik (Pemilihan Umum Presiden) di Indonesia dan Singapura (Studi Kasus Terhadap Perusahaan Kelompok LQ45 Di BEI dan Strait Times Index di SGX). E-Proceeding of Management, 2(2), 1640-1648.

Nazir, M. S., Younus, H., Kaleem, A., \& Anwar, Z. (2014). Impact of Political Events on Stock Market Returns: Empirical Evidence From Pakistan. Journal of Economic and Administrative Sciences, 30(1), 60-78. https://doi.org/10.1108/jeas-03-2013-0011

Niam, N. Y., Achsani, N. A., \& Maulana, T. N. A. (2018). Impact of Donald Trump Election on Global Indexes. International Journal of Business and Management Review, 6(3), 1-16.

Obradovic, S., \& Tomic, N. (2017). The effect of presidential election in the USA on stock return flow - a study of a political event. Economic Research-Ekonomska Istrazivanja, 30(1), 112-124. https://doi.org/10.1080/1331677X.2017.1305802

Pratama, I. G. B., Sinarwati, N. K., \& Dharmawan, N. A. S. (2015). Reaksi Pasar Modal Indonesia Terhadap Peristiwa Politik ( Event Study pada Peristiwa Pelantikan Joko Widodo Sebagai Presiden Republik Indonesia Ke-7 ). E-Journal S1 AK Universitas Pendidikan Ganesha, 3(1).

Rahmawati, I. A., \& Achadiyah, B. N. (2015). Analisis Perbedaan Abnormal Return Saham Sebelum dan Sesudah Putusan Sidang Sengketa Pemilu Presiden 2014 (Studi Kasus Saham di Bursa Efek Indonesia). Jurnal Akuntansi Aktual, 3(1), 1-10.

Republik Indonesia. Undang-Undang Nomor 8 Tahun 1995 Tentang Pasar Modal., Pub. L. No. Lembaran Negara RI Tahun 1995, No.64 (1995).

Sasongko, J., Widiyanti, M., \& Taufik. (2015). Reaksi Pasar Modal Atas Peristiwa Pengumuman Presiden Ri 2014 (Studi Pada Saham Sektor Pertambangan Di Bursa Efek Indonesia). Jembatan : Jurnal Ilmiah Manajemen, 12(1), 33-44. https://doi.org/10.29259/jmbt.v12i1.3123

Sudewa P., D. G. O., \& Sari, M. M. R. (2015). Reaksi Pasar Atas Peristiwa Pilpres 2014. E-Jurnal Akuntansi Universitas Udayana, 12(3), 465-480.

Suharyati, S., \& Hermuningsih, S. (2014). Analisis Perbedaan Abnormal Return dan Volume Perdagangan Saham Sebelum dan Sesudah Pilpres 9 Juli 2014 (Studi Kasus Perusahaan Milik Bakrie Group dan MNC Group). Jurnal Manajemen, 4(2), 15-20. 
https://doi.org/10.26460/jm.v4i2.171

Tandelilin, E. (2017). Pasar Modal: Manajemen Portofolio dan Investasi. Yogyakarta: PT Kanisius. 